\title{
The Void of Chineseness: Contemporary Art and Cultural Diplomacy in China
}

\author{
Yao Yung-Wen
}

\begin{abstract}
This paper looks at China's official cultural identity that has been constructed as discourses and used as China's soft power as reflected in contemporary Chinese art externally and internally. The Chinese Government constructed a unitary official cultural identity to ensure China's social cohesion and national unity when communist ideology was no longer upheld as China's central belief system after Deng Xiaoping's economic reforms in 1979. "Chinese culture" has been regarded as the core of China's soft power in exercising China's cultural influence in the face of Western cultural imperialism in the post-Mao era in which China's rapid economic growth has largely strengthened the nation's confidence in asserting its position on the global stage and in holding its own world view. This paper argues that there is, however, a void behind China's soft power. The recuperation of China's traditional culture and Confucianism is more of a strategic political language than a return to an "authentic" cultural root.
\end{abstract}

Index Terms-Cultural identity, cultural diplomacy, soft power, contemporary Chinese art.

\section{INTRODUCTION}

China's official cultural identity has been reconstructed since 1979, when the Chinese Communist Party (CCP) state decided to participate in the capitalist market economy, and since the 1990s the CCP has employed contemporary Chinese art in China's cultural diplomacy to articulate China's national identity as a 'Chinese nation' both internally and externally. China desired a position of world economic, political and cultural importance, and when Party decided that China's national culture should be the core of its soft power, China attempted to project a unified cultural image which was believed to be distinct from others in the global community. Consequently, China's cultural diplomacy has aimed to promote Chinese culture abroad and defend China's cultural security in the face of the growing cultural influence from the West. Contemporary Chinese art, after achieving its international success in the 1990s, has been co-opted as an significant part of China's cultural diplomacy in promoting China's national image abroad.

\section{MAIN BODY}

As observed in the report, China's National Defense in 2006, "never before has China been so closely bound up with the rest of the world" [1]. According to Andrew J. Nathan and

Manuscript received June 10, 2014; revised August 3, 2014.

Yao Yung-Wen is with the Culture Film and Media Department, University of Nottingham, Nottingham, NG7 2RD, UK (e-mail: ajxyy1@ nottingham.ac.uk).
Andrew Scobell, "China's soft power in the early twenty-first century rose in conjunction with its economy, underscoring the reality that a significant accumulation of hard power is a precondition for generating appreciable soft power" [2].

Consequently, exerting China's cultural influence overseas became an imperative part of China's global strategy. However, a "Chinese China" has been regarded as a "backward" force since imperial China was overturned in 1919. In order to "modernize" China, Western political systems were adopted after 1919 and under the communist regime since 1949, "Chinese tradition" had been believed to be responsible for the failure of China's previous attempts to modernise, to the point where it was decided that it should be completely abandoned during the Cultural Revolution. Therefore, when the Chinese Government decided not only to change its economic system but also to redefine its identity as a "Chinese" nation, defining that Chinese identity became problematic.

In promoting this Chinese identity, the Party has utilized contemporary Chinese art - as opposed to traditional folk art-as the "additional element" of China's cultural diplomacy. The inclusion of contemporary Chinese art as China's diplomatic language to display a modern and open "Chinese China" thus can be pertinently used in analysing how the idea of "Chinese culture" is interpreted and represented in both official and unofficial discourses in relation to the rising forces of nationalism, Confucianism and postcolonial discourse in China.

According to the prevailing postcolonial discourses, it is problematic to claim an original and authentic cultural root to "return to" given that disruptions and discontinuities of history, global economic interdependence and international emigration all seriously challenge the concept of the nation state and the definition of national culture. The assertion of a "singular national identity" became problematic when foreign cultural influences were internalised as part of everyday life. The hybridity of contemporary Chinese society also challenged the idea of "cultural homogeneity". When the CCP introduced a capitalist economy, it was made clear that communism would no longer be the central belief that maintained China's social cohesion and national unity. Joining the international community not only meant that China had to open and change its once-isolated system in order to be connected with international organisations and their rules, but also placed China under the evaluation of a set of "universal"/Western values. It became urgent for the Party to reposition itself to deal with the external and internal demands of a new identity.

During the 1980s, the significant Western cultural influence on Chinese society was deemed to be responsible 
for the Tiananmen crackdown in 1989. The '85 Art NewWave also ended with controversy in the same year. China's avant-garde art, like the student movements that were once regarded as liberal pursuits, was to blame for causing social upheaval and chaos. Contemporary Chinese art was officially banned from any public sphere as a consequence. With the advanced participation in the international community, the CCP found it had to accept a set of universal values that ultimately influenced its domestic affairs and put its legitimacy in crisis. By asserting that this set of universal values served "the idea of the centrality of the West", the Party decided it was of crucial importance to "emphasize and strengthen the study of the differences between Eastern and Western culture" [3]. The idea of Asian values was supported by the Chinese Government, which stated that Asia could provide an alternative to the Western way of life [3]. In order to distinguish Chinese values from the Western-centred universal values, traditional Chinese culture was re-evaluated as the authentic roots of China's own cultural values instead of a backward force, which was how it had been labelled since the early twentieth century. Also, when socialism had become increasingly distanced from social reality, the communist ideology was regarded by cultural nationalists as one of those Western theories that should be excluded from the search for "authentic Chinese cultural roots". In other words, in addition to the necessity of defining China's global role as a "Chinese nation," the Party also needed to reconstruct its identity as representing the "Chinese people" instead of the great proletarian class in order to continue the Party's legitimacy in ruling the country.

A "Chinese" China was certain to be antagonistic to the Western-centred "universal" values. However, what exactly constituted "Chineseness" remained ambiguous. This ambiguity is revealed in particular in discussions related to contemporary Chinese art. In contemporary China the understanding of concepts such as cultural diplomacy, nationalism, postcolonialism, modernity and contemporary Chinese art was often based on reinterpretations of those concepts that were consistent with China's national interests, which were basically conflated with the Party's interests. To put it another way, things had to be read in the "Chinese" way, usually involving a nationalist sentiment. Still, "Chineseness" is an undefinable concept in contemporary China. Therefore, I argue that there is a void behind the concrete assertion of China's official cultural identity. Like China's nationalism, identity became a political ideology influenced by China's national interests; however, behind this identity is an ambiguous assertion of the glorious past and an ongoing anti-imperialist sentiment. The "Chineseness" promoted in contemporary Chinese art practices bears the same hollow face that is manifested in China's cultural diplomacy. It is difficult to grasp what constitutes the communally inspired vision of identity other than a powerful China, nourished by the growing importance of "Chineseness" in defining China's cultural identity.

Still, it would be wrong to assume that social reality was fully manifested in the dominant official discourse. A unified "Chinese" identity failed to explain the reality of contemporary Chinese society. Yet the distinction between Chinese culture and Western culture has been firmly asserted by the Chinese Government and supported by Chinese intellectuals and art practitioners. China's Middle Kingdom complex holds that China's great civilisation will eventually assimilate contradictory elements from other cultures while retaining the Chinese essence. The CCP's re-evaluation of traditional culture, especially Confucianism, significantly strengthened the cultural nationalists' confidence in this belief. By holding the conviction of cultural superiority, the ancient Chinese refused to "acknowledge a world of formally equal nation-states" and insisted that legitimate rule rested on "adherence to Confucian norms, which dominated the development of Chinese culture for more than one thousand years" [4]

Moreover, by conflating nationalism with its patriotic education, the CCP also silenced cultural nationalists' questions towards its "alien nature": communism. As Jiang Zemin stated, "in China today, patriotism and socialism are unified in essence" [5]. As Zhao has argued, there are two sides to China's growing nationalism [6]. On the one hand, China's nationalism had a clear goal, which "was intrinsically linked with meeting the challenge of the West" [7]. It was of crucial importance for China to "find its own unique path toward modernization," and "Chinese nationalism should help China reconstruct its own national identity 'from a synthetic combination of the best elements from the traditional and the modern, East and West"' [7]. On the other hand, taking Lucian Pye's point of view, China's nationalism was deeply linked with the interests of the communist state. That is to say, essentially, "Chinese nationalism ... suffered from a "lack of content"” [8].

"Pye has pointed to a void in the cultural ideas that could provide the substantive content for Chinese nationalism because the historical legacies of Chinese tradition have long been under heavy attack since the May Fourth movement of 1919. In particular, forty years of sustained attacks by the communist regime on traditional Chinese culture left China with a relatively inchoate and incoherent form of nationalism without a substantive core that could be readily articulated [8]."

Pye believes that "Chinese nationalism in the PRC was reduced to the expression of a political party's current policies," which contributes to Chinese intellectuals' inability to grasp concrete problems of cultural change. Responding to Pye's argument, Lowell Dittmer and Samuel Kim argue that China, "with its legitimate monopoly on violence and its controlling interest in terms of manipulating the national symbol system, plays a determining role in the construction and management of a national identity dynamic" [8].

Martina Köppel-Yang provides insightful arguments about how the national symbol system was manipulated in the PRC through a semiotic analysis of contemporary Chinese works of art from the 1980s.

"The art of the Chinese avant-garde of the 1980s rather tends to be an extension of the dominant culture, as it develops in a semi-official space and forms a kind of symbiosis with the official culture. Its definition of a modern Chinese identity is further more or less tightly related to the 
official program of modernization. ... [The semiotic analysis] will show how a Chinese culture identity is defined in the works of art. ... Official and alternative strategies of interpretation are to be uncovered [9]."

Drawing on Igor Golomstock's work in Totalitarian Art, Köppel-Yang believes that the exploitation of art in the service of ideology began early in China with the Chinese modernisation movement in 1917 and continued to be used by the CCP as "the strategic employment of images and signs by the official side" [10]. She further states that during the Cultural Revolution, "the total aestheticisation of all aspects of life" eliminated the boundary between art and life and "in Deng's era these basic principles did not change" [10]. In her view, even the "alternative trends" of Chinese artists in the 1980s were impregnated with the impression that the function of art was mainly in the service of ideology and discourses, which was a legacy of the Cultural Revolution [11]. Köppel-Yang argues that works of art and discourses in China formed a dialectical relationship because both the Government and artists believed that images were endowed with a transformational power that could achieve the ideological or moral transformation of society. She terms the function of art in a totalitarian system "the strategies of representation and interpretation" due to the fact that art practices were conditioned with social and political norms, a set of cultural value concepts and discursive practices. The identity, as engendered values, was hence evident in the collective visual expressions.

If the development of contemporary Chinese art in the 1980s witnessed the continuous connection between art and official discourse domestically, the internationalisation of contemporary Chinese art in the 1990s revealed China's concern of projecting its image globally. Nathan and Scobell contend that the CCP's emphasis on contemporary Chinese art in the 1990s was less a coincidence than a strategy for its diplomatic breakthrough in the West. As a result, contemporary Chinese art mainly reveals conflicts between China and the West, rather than tensions between China and other Asian countries. Nevertheless, the way that contemporary Chinese art represented China's international image in the early 1990s was not entirely under the CCP's control. The international prestige of contemporary Chinese art was brought about by Western curators' and institutions' promotion, selection and interpretation. Their "interpretation" of contemporary Chinese culture inevitably evoked the Chinese Government's and mainland Chinese intellectuals' nationalist sentiment. The debate between mainland Chinese artists and overseas Chinese artists over who had the right to represent and interpret China was one of the examples that revealed the tension engendered when Chinese culture was believed to be subjected to Western value judgements. The emergence of a large number of contemporary museums, biennales and triennials demonstrated the Chinese Government's resolution to tighten the control of its discursive power in contemporary Chinese art. According to The Economist:

"In 1949, when the Communist Party took control, China had just 25 museums. ... According to the current five-year plan, China was to have 3,500 museums by 2015, a target it achieved three years early. Last year [2012] a record 451 new museums opened, pushing the total by the end of 2012 to 3,866, says An Laishun, vice-president of the China Museums Association. By contrast, in America only 20-40 museums a year were built in the decade before the 2008 financial crash [12]."

Chinese officials pointed out that "the great cities of the world - New York, Paris, London - all have important museums and China should too" [12]. They believed that it was important to "show off their ancient culture to locals and foreigners alike, and talk of the importance of remembering the past and of educating the younger generation" [12]. In 2009, government policy already defined Chinese culture as a strategic "pillar industry" and stressed that Chinese culture was the "spirit and soul of the nation" and hence "a powerful force for the country's development" [12]. The largest contemporary art museum in the world will also be opened in Beijing in 2017.

"Museums are an integral part of this policy, and they are multiplying rapidly — too rapidly in many cases. ... In Beijing the government is planning to turn part of the Olympic park, built for the 2008 games, into a culture hub. ... One of the star attractions will be the new National Art Museum of China (NAMOC). ... The new NAMOC, close to the 798 art district ... will be six times as big as the current museum. The winning bid for its design, by Jean Nouvel, a French architect, is based on the Chinese symbol for the number one [12]."

Contemporary Chinese art played an important role in projecting China's international image yet was deeply associated with Western evaluation systems and rules. The CCP monitors contemporary art practices by placing them under implicit, rather than explicit, rules. For the thousands of museums in China, despite the fact that a Ministry of Culture Notice in 2001 officially enabled local governmental units to monitor contemporary art exhibitions, the rules to judge why a certain work of art was or was not permitted to be displayed in a public space were never made explicit. In most cases, the right of interpretation was left to the local authorities, who rarely referenced professional opinions. As The Economist put it, "in contemporary art, with its ironies and its multiple readings, Chinese artists test the patience of officialdom. The boundaries are fluid, but most Chinese know how far they can push them" [12].

The Party sought to homogenise ideas and elements of contemporary art practices in China and to place Chinese artwork within its own evaluation system. The Chinese pavilion at the Venice Biennale and the Shanghai Biennale were two cases of this will. "Authentic Chineseness" and a "modernised China" were themes that could easily be traced in their exhibitions. The Chinese pavilion at the $54^{\text {th }}$ Venice Biennale adopted unmistakeable traditional Chinese symbols to represent contemporary China but was generally perceived to be a failure by mainland Chinese art critics, art scholars, the art media and artists. The exhibition delivered a strong message of "traditional Chinese culture" but failed to explain its relationship with contemporary Chinese society. The selected objects, such as wine, still existed in contemporary 
China, but the exhibition failed to elucidate why they were chosen to be placed in the global context other than to demonstrate the greatness of Chinese culture.

Alternative discourses proposed in China also revealed the persistence in searching for China's own cultural roots. If it were wrong to assume a homogeneous cultural identity in China, the prevailing upholding of the ambiguous 'Chineseness' directed by the official discourse demanded more explanation. As China's nationalism, the asserted 'Chineseness' seemed to be a strong voice with a void in essence. The concerted responses in interviews I conducted in 2011 pertinently echoed this paradox. When asked who could best represent contemporary Chinese art, almost all the interviewees gave the same firm response: 'No one.' They went on to state that 'every artist's work is part of contemporary Chinese art but none of them represents contemporary Chinese art'.

Homi K. Bhabha's theory of the Third Space contends that 'the meaning and symbols of culture have no primordial unity or fixity; ... even the same signs can be appropriated, translated, rehistoricized and read anew' [13]. Regarding the structure of meaning and reference as an ambivalent process, Bhabha rejects the reading of cultural knowledge as an integrated unit. He challenges the perception of the historical identity of culture as "a homogenizing, unifying force, authenticated by the originary Past, kept alive in the national tradition of the People" [14]. He remarks that "it is only when we understand that all cultural statements and systems are constructed in this contradictory and ambivalent space of enunciation, that we begin to understand why hierarchical claims to the inherent originality or 'purity' of cultures are untenable, even before we resort to empirical historical instances that demonstrate their hybridity" [13].

Bhabha holds that the revisiting of the Past did not connect the present with an "origin" of the past. On the contrary, it "renewed" the past, "refiguring it as a contingent 'in-between' space, that innovates and interrupts the performance of the present" [15]. In this sense, "the 'past-present' becomes part of the necessity, not the nostalgia, of living" [15]. The CCP's re-evaluation of the past, similarly, never meant to re-pose the past as a definite resource for the present. Just like the upholding of Confucianism, it would be a mistake to read the CCP's gesture as re-embracing Confucian values. In other words, the "Chineseness" was used more to define the "Other" than to define the "Self". Although nationalism and Confucianism in China were of crucial importance in reinventing China's official cultural identity, the values they promoted were by no means allowed to override the Party's interests. The extent to which nationalists and Confucians could engage with society was restricted by the Party's implicit policies. As the "additional elements" that the CCP adopted to reconstruct its identity in order to consolidate its rule, drawing on Foucault's theory, the mechanisms brought into play in power relations were "strategies" [16]. These "strategies" renewed the past while claiming a return to the past and brought instabilities to the Party's rule, as they contradicted the Party's socialist identity.

Though he mainly refers to the minority discourse in postcolonial nations, in Bhabha's opinion the origin of the national community, the "many as one", as being gradually diminished by the "less-than-one" which undermined the homogenous totality with an iterative temporality [17]. He criticises the concept of "cultural diversity" for its recognition of "pre-given cultural contents and customs" and its subsequent upholding of "multiculturalism", which admitted "the Utopianism of a unique collective identity" [ 18 ]. Instead, he advocates the concept of "cultural difference," which focuses on "the problem of the ambivalence of cultural authority: the attempt to dominate in the name of a cultural supremacy which is itself produced only in the moment of differentiation" [19]. Consequently, the pursuit of the very authority of culture as a knowledge of referential truth would ultimately witness the split of cultural identification, which, according to Bhabha, is 'a split between the traditional culturalist demand for a model, a tradition, a community, a stable system of reference and the necessary negation of the certitude in the articulation of new cultural demands, meanings, strategies in the political present, as a practice of domination, or resistance' [19].

The split in the performative present of cultural identification in China, however, was ignored by the more pressing common pursuit: an independent and powerful China. As Chinese scholars pointed out, if a choice had to be made between a powerful China and a democratic but chaotic China, most people, including intellectuals, would opt for the former. Therefore, a stable system of reference in terms of authentic Chinese cultural roots was necessary in order to support China's official cultural identity and China's global role. As a consequence, when mainland Chinese art scholars, art critics and artists attempted to criticise the Government for merely showing a "Chinatown culture" by juxtaposing the Chinese pavilion at the Venice Biennale with the "Chinese Years" projects organised by the Chinese Government to promote Chinese culture overseas, they also failed to provide a more convincing interpretation of "Chineseness".

The uncertain, unstable and ambivalent elements engendered by the collision of cultures, as Bhabha states, denotes the vulnerability of an assertive and authoritative cultural identity. However, he does not explain how alternative discourses actively contributed to a collusive present in a totalitarian system. The complicity in effect between official and unofficial/alternative discourses may be regarded as a necessary strategy for unofficial/alternative discourses to become the "supplementary" element of the powerful official discourse. Still, it remains unclear how alternative discourses can internalise their values as part of the official identity when the discursive power was under strict control. Also, although Bhabha's concept of the "resettlement of the borderline" sees identity as being "performatively" formed through the iteration and recreation of the "self", the ideas that influence the performative formation of identity in China are different. Traditional Chinese philosophy, in fact, highly valued the concept of "pre-given cultural contents and customs" in the way Bhabha criticises. That is: different cultures would be accepted and assimilated as long as a pre-given condition to recognise the "Chinese" culture as the supreme culture was ensured. 


\section{CONCLUSION}

In conclusion, China's official cultural identity has been reconstructed in accordance with the Party's interests. Traditional cultures have been re-evaluated as China's cultural root to bolster China's national culture which has been defined as the core of China's soft power. The continuous tension between China and the West has helped the CCP to reconstruct its Party identity as China's national identity and the 'Chineseness' has been treated as essential in equipping China in the global power struggle. Contemporary Chinese art not only reflects the tension between China and the West but also exemplifies the complexity of China's reconstructed official cultural identity. Moreover, contemporary Chinese art has continued to serve political ideology in different forms in post-Mao China. I have argued that in the case of China, despite their contesting meanings, alternative discourses ultimately form a concerted voice that the official discourse can take advantage of and further co-opt as an integral part of China's soft power. The "resettlement of the borderline" of identity in China does not form a challenge to this pursuit. On the contrary, the 'alternative voices' frequently join this pursuit in an implicit way. The incorporation of conflicting elements and the utilization of the ambiguous definition of 'traditions' demonstrate a void of "Chineseness" rather than providing an authentic root of Chinese culture. The void of "Chineseness", essentially, does not bring traditional values as the supplement of the current dominant belief system. Rather, with clear political goals, it renews the past and covers contesting meanings and ambiguous definitions in reconstructing the present.

\section{REFERENCES}

[1] A. J. Nathan and A. Scobell, China's Search for Security, New York: Columbia University Press, 2012, p. 35.

[2] A. J. Nathan and A. Scobell, China's Search for Security, New York: Columbia University Press, 2012, p. 321.

[3] A. J. Nathan and A. Scobell, China's Search for Security, New York: Columbia University Press, 2012, p. 331.
[4] S. S. Zhao, A Nation-Sate by Construction: Dynamics of Modern Chinese Nationalism, California: Stanford University Press, 2004, ch. 3, p. 42.

[5] A. J. Nathan and A. Scobell, China's Search for Security, New York: Columbia University Press, 2012, p. 9.

[6] A. J. Nathan and A. Scobell, China's Search for Security, New York: Columbia University Press, 2012, p. 42.

[7] A. J. Nathan and A. Scobell, China's Search for Security, New York: Columbia University Press, 2012, p. 13.

[8] A. J. Nathan and A. Scobell, China's Search for Security, New York: Columbia University Press, 2012, p. 14.

[9] M. K. Yang, Semiotic Warfare: The Chinese Avant-Garde 1979-1989. A Semiotic Analysis, Hong Kong: Timezone 8 Limited, 2003, p. 36.

[10] M. K. Yang, Semiotic Warfare: The Chinese Avant-Garde 1979-1989: A Semiotic Analysis, Hong Kong: Timezone 8 Limited, 2003, Advocated by the minister of education and the head of Beijing University, Cai Yuanpei, 2003, p. 37.

[11] Chinese artists and art groups in the 1980s actively offered their interpretations of and assertions about their works of art in magazine articles or through other available media channels.

[12] Anonymous. (21 December 2013). Mad about Museums. The Economist. [Online]. Available: http://www.economist.com/news/special-report/21591710-china-build ing-thousands-new-museums-how-will-it-fill-them-mad-about-museu $\mathrm{ms}$

[13] H. K. Bhabha, The Location of Culture, London: Routledge, 1994, p. 55.

[14] H. K. Bhabha, The Location of Culture, London: Routledge, 1994, p. 54.

[15] H. K. Bhabha, The Location of Culture, London: Routledge, 1994, p. 10.

[16] H. K. Bhabha, The Location of Culture, London: Routledge, 1994, p. 33.

[17] H. K. Bhabha, Nation and Narration, Routledge, 1990, pp. 305-306.

[18] H. K. Bhabha, The Location of Culture, London: Routledge, 1994, p. 50.

[19] H. K. Bhabha, The Location of Culture, London: Routledge, 1994, p. 51.

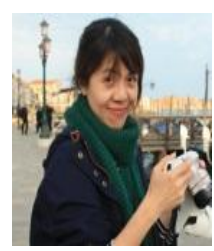

Yao Yung-Wen is a $\mathrm{PhD}$ candidate at the University of Nottingham. Her research interests include China's cultural diplomacy and contemporary Chinese art. She gained her first MA in China's diplomacy from Peking University before going on to complete her second MA in cultural studies at Goldsmiths College, the University of London. 